\title{
C.S. Lewis and his works, with Special Emphasis on 'Chronicles of Narnia'
}

\section{Sunita David}

\section{INTRODUCTION}

C.S. Lewis was a prolific Irish writer and scholar best known for his Chronicles of Narnia fantasy series as well as his Christian texts. Born on November 29, 1898, in Belfast Ireland, C.S. Lewis went on to teach at Oxford University and became a renowned apologist writer, using logic and philosophy to support the tenets of his Christian faith.

Lewis graduated from Oxford University with a focus on literature and classic philosophy, and in 1925 was awarded a fellowship teaching position at Magdalene College, which was part of the university. There, he also joined the group known as The Inklings, an informal collective of writers and intellectuals who counted among their members Lewis' brother, Warren Lewis, and J.R.R. Tolkien. It was through conversations with group members that Lewis found himself re-embracing Christianity after having become disillusioned with the faith as a youth.

The Chronicles of Narnia is a series of seven fantasy novels by author C. S. Lewis. It is considered a classic of children's literature and is the author's best-known work, having sold over 100 million copies in 47 languages. Written by Lewis between 1949 and 1954, illustrated by Pauline Baynes and originally published in London between October 1950 and September 1956, The Chronicles of Narnia has been adapted several times, complete or in part, for radio, television, the stage, and film.

The natural world Lewis created and its inhabitants whom he called Narnians were animals that talked, there were also mythical creatures from Classical mythology; namely the fauns, satyrs, centaurs, dryads, and others. This introduces the idyllic pastoral ambience of the classics to Narnia. The animals do not lend themselves to any interpretation, but are reminders of an old world of fantastic creatures also longing for the restoration of Eden or Paradise just as man does. The land of Narnia has an order or line of humans in the medieval tradition of a bygone era of knights with their strict code of honour. Bravery on the battlefield and chivalry to the weak were the ideals of their court life.

The theme of the natural world's longing for deliverance from the curse of a fallen world is echoed in man. The theme of sin and deliverance of a fallen world is the moral universe that pervades the Chronicles of Narnia.

The very first element of Narnia came to Lewis when he was sixteen. He saw in his imagination a faun (a mythological creature like a man with goat legs) carrying parcels in a snowy wood. The image stayed with him, and many years later it found a place in the opening of 'The Lion, the witch and the wardrobe' the first of his Narnia stories.

It is a fact that Lewis set out from the beginning to re-tell the Christian plan of redemption; Aslan, the Christ-like lion, was not even thought of, until some way into the story. Then, as Lewis put it, he "came bounding into it" and brought with him all the ideas Lewis needed to finish the book.

Inspiration for the series is taken from multiple sources; in addition to adapting numerous traditional Christian themes, the books freely borrow characters and ideas from Greek and Roman mythology as well as from traditional British and Irish fairy tales. The books have profoundly influenced adult and children's fantasy literature since World War II.

\section{Fantasy and Values woven together}

Lewis Carroll's 'Alice in Wonderland' and 'Through the Looking-glass' have this in common with C.S. Lewis 'Chronicles of Narnia' that they lead us into a world of fantasy and they both belong to the genre of children's fiction. The similarity ends here. The frame work for the stories makes all the difference. Alice in Wonderland follows a dream-reality and the key to self-discovery lies within the child, Alice. The Chronicles of Narnia have the Christian premise as their foundation. The value of Childhood and the necessity of sacrifice in love are its embedded values. Nature has a role to play all through in the history of man and nature, where the salvation of one implies the salvation of the other. This runs throughout the tales of Narnia.

The value of childhood

Matthew 18:3 (RSV) “Truly I say to you unless you turn and become like children you will never enter the kingdom of heaven." Based on this stipulation of Christ found in the book of Matthew of the New 
Testament-The Bible, begins a story with children as its characters living out the truths of the kingdom of heaven; not in a perfect garden of Eden but in a fallen world where sin and evil co-exist and poses a challenge to all kingdom values. The quality of childlikeness opens the doors of Narnia to the characters who stumble on it presumably by accident.

The talking animals and the regular ones are waiting eagerly for their redemption from the curse of the White Witch who imposes winter permanently on Narnia. With Aslan-the lion by their side the children go about rescuing the land and the animals from the curse of a Winterland, bringing back Spring to Narnia. Aslan is betrayed by Edmund who has fallen to the temptation of the sweet Turkish delight offered by the White Witch. Doomed to die and betrayed by one of his own, Aslan rises again to defeat evil and to claim victory over the forces of the White Witch.

\section{Death and Renewal}

If a grain of wheat fall to the ground and die, it shall bring forth much fruit- ............This analogy is given by Christ from the natural world concerning the death and resurrection of the body. This is worked out in the Christ-likeness of Aslan the creator of Narnia. Christ is also called the Lion of Judah and Lewis intended the lion Aslan to stand for Christ. The power to break the curse and defeat the enemy comes only after Aslan's humiliation and death at the hands of the White Witch and her followers. The shame of the cross-Christ's deathHis resurrection is imitated in the figure of Aslan, the lion.

\section{Resurrection and Triumph}

Each book from the Chronicles of Narnia shows the victorious life versus the defeated one. To hold on to the triumph is now the responsibility of the Narnians. Any falling away from the kingdom values, results in the re-entry of the White Witch into Narnia. The sons and daughters of Eve, that is the children intercede and reclaim Narnia for the Narnians. The inter-textuality of the real world and the fantasy gives an opportunity for clear outlining of the physical reality as in World War II affected London versus the moral universe which is no less real as the material one. Man's responsibility towards nature is a moral duty and keeping it that way is the whole plan on which 'Chronicles of Narnia' works on.

\section{The story form: Allegory, Fairy-tale, Mythology}

Childhood and stories go together. They help children understand the world they live in. Not all stories end happily-ever-after, and Hans Christian Anderson wrote a few fairy tales with mixed endings: The Little Mermaid, The Steadfast Tin Soldier, The Snow Queen, The Emperor's New Clothes. The brothers Grimm gave us old classics like: Snow White and the seven dwarves, Rapunzel, Cinderella to name a few. These begin with "Once-upon-a time" and end "happily-ever-after." Apart from fairy tales children also grow up on mythology that is stories of a people, on a grander scale than grandmas' tales that are about family. Given the many forms available for storytelling, C.S. Lewis chose the fairy-tale. He spoke of his love of writing fairy tales in his essay "Sometimes Fairy Stories May Say Best What's to Be Said:" "I fell in love with the [fairy tale's] form itself: its brevity, its severe restraints on description, its flexible traditionalism, its inflexible hostility to all analysis, digression, reflections and 'gas.' I was now enamored of it. Its very limitations of vocabulary became an attraction; as the hardness of the stone pleases the sculptor or the difficulty of the sonnet delights the sonneteer. On that side (as Author) I wrote fairy tales because the Fairy Tale seemed the ideal Form for the stuff I had to say".

Many argue for Narnia as a biblical allegory. There is symbolism but one-to-one identification or personification of values or animals does not hold good for Narnia. An allegory is a literary device in which an author uses the form of a person, place, or animal to represent an abstract idea. In a letter to a little girl he explains his idea of supposal as being different from the allegory.

\section{Idea of supposal}

In a December 1959 letter to a young girl named Sophia Storr, he explains the difference: "I don't say. 'Let us represent Christ as Aslan.' I say, 'Supposing there was a world like Narnia, and supposing, like ours, it needed redemption, let us imagine what sort of Incarnation and Passion and Resurrection Christ would have there.' Allegory and supposal aren't identical devices, according to Lewis, because they deal with what's real and what's unreal quite differently. In an allegory, the ideas, concepts, and even people being expressed are true, but the characters are make-believe. They always behave in a way reflective of the underlying concepts they're representing".

Allegory carries the polarities of true and make-believe. In supposal the real and unreal blend together, much like an animation movie with a mix of animated characters and flesh-and -blood ones. They move in the same space being moulded by the narrative. They do not follow the polarization of 'real' and the 'unreal' as in an allegory. The divide is blurred in the method of 'supposal'. Mr. Tummnus-the faun, centaurs, the talking 
animals and the kings and queens of Narnia interact with the reader's "willing suspension of disbelief" taken for granted as in a fairy-tale. The stories are given the underlying bed-rock values that all human beings understand. The values of fair-play, friendship, loyalty, love and sacrifice lead to the miracle of triumph of good over evil. This ultimately is the rationale of the Chronicles of Narnia.

\section{CONCLUSION}

Weaving stories is one of man's first steps towards development. Spanning creation to death then resurrection, Chronicles of Narnia brings across the story of the evolution of man morally. In the genre of a fairy-tale it brings along the feel-good factor and fantasy as well. The truths of renewal and preservation of man and nature still captures man's imagination and inspires. Finally it is the truths contained in the Chronicles of Narnia and the childhood sense of wonder it captures that makes it a classic. In the words of C. S. Lewis: "Someday you will be old enough to read a fairy-tale again"

\section{REFERENCES}

[1]. www.biography.com/people/cs-lewis-9380969

[2]. www.bbc.co.uk/religion/religions/christianity/people

[3]. Myth Made Truth: The Origins of the Chronicles of Narnia by Mark Bane

[4]. Chronicles of Narnia: Masterpiece of Christian Allegory by Steve Bonta from 'The New American' Friday, 10 December 2010.

[5]. www.narniaweb.com/wp-content Chapter 6: Allegory and Symbolism: Deciphering the Chronicles. 